\title{
THE EFFECT OF COPPER ON HUMAN ERYTHROCYTE GLUTATHIONE REDUCTASE
}

\author{
J. P. FLIKWEERT
}

Clinical Chemical Department, Diakonessenhuis, Naarden

R. K. J. HOORN

Clinical Chemical Department, Diakonessenhuis, Hilversum

\author{
AND \\ G. E. J. STAAL
}

Unit of Medical Enzymology, State University Hospital, Utrecht, The Netherlands

(Received I5 March 1974)

\begin{abstract}
I. The influence of copper on purified human erythrocyte glutathione reductase (E.C. r.6.4.2) was studied. The holoenzyme was inhibited at low oxidized glutathione (GSSG) concentrations. At a glutathione concentration of $\mathrm{I} \mathrm{mM}$ and higher no inhibition at all was found. The inhibition was independent of the concentration of NADPH.

2. When the holoenzyme was preincubated with copper much more inhibition was found. This inhibition could be prevented by adding oxidized glutathione to the incubation mixture.

3. The recombination of the apoenzyme with FAD was inhibited by copper. This inhibition by copper was competitive with respect to FAD.
\end{abstract}

Glutathione reductase $(\mathrm{NAD}(\mathrm{P}) \mathrm{H}$ : oxidized glutathione oxidoreductase, E.G. I.6.4.2) catalyzes the reaction

$$
\mathrm{GSSG}+\mathrm{NADPH}+\mathrm{H}^{+} \leftrightharpoons 2 \mathrm{GSH}+\mathrm{NADP}^{+} .
$$

Glutathione reductase is a flavoprotein and contains $\mathrm{FAD}$ as prosthetic group (Icén, I967; Staal, Visser \& Veeger, 1969).

Raised levels of free serum copper and erythrocyte copper cause hemolytic anaemia, which is seen in Wilson's disease (Deiss, Lee \& Cartwright, 1970) and in rare cases of copper poisoning by renal hemodialysis equipment (Manzler \& Schreiner, I970), following ingestion of copper salts or topical application of copper sulphate solutions to denuded skin. Increased copper levels are also found in patients with various haematological disorders (Boulard, Blume \& Beutler, 1972). For this reason the influence of copper on several enzymes from the red cell has been studied. Inhibition at nearly physiological levels of copper has been reported for the enzymes hexokinase, phosphofructokinase, phosphoglyceric kinase, 6-phosphogluconate dehydrogenase (Boulard et al., 1972) and pyruvate kinase (Boulard et al., 1972; Willms, Blume \& Löhr, 1972). Other investigators reported the inhibition by copper for glucose-6-phosphate dehydrogenase (Fairbanks, I967) and glutathione reductase (Deiss et al., 1970).

Willms et al. (1972) and Boulard et al. (1972), however, did not observe any influence of copper on glutathione reductase. Metz \& Sagone (1972) reported a decreased level of red cell reduced glutathione, not caused by enzyme inhibition but by catalytic auto-oxidation and oxidative stress on the red cell.

In view of these contradictory reports we studied the effect of copper on purified glutathione reductase isolated from human red cells. We also studied the effect of copper on the recombination of the glutathione reductase apoenzyme with FAD. 


\section{MATERIALS AND METHODS}

\section{CheMicals}

NADPH, FAD and GSSG were obtained from Boehringer and Soehne. DEAE-Sephadex A-5o, capacity $3.5 \pm 0.5 \mathrm{meq} . / \mathrm{g}$., partical size $40-$ I20 $\mu \mathrm{m}$. and CM-Sephadex C-50, capacity $4.5 \pm 0.5 \mathrm{meq} / \mathrm{g}$., partical size $40-120 \mu \mathrm{m}$. were purchased from Pharmacia, Uppsala. Human erythrocytes were obtained from healthy donors from the Netherlands Red Cross Blood Transfusion Service. In the copper experiments $\mathrm{CuSO}_{4}$ was used.

\section{Determination of Activity}

The assays were carried out, at $25^{\circ} \mathrm{C}$, (with a Zeiss spectrophotometer PMQII in combination with a Vitatron UR 4or recorder) by following the change in extinction at $340 \mathrm{~nm}$. due to the oxidation of NADPH with GSSG as acceptor (Staal et al., ig6g). NADPH-GSSG reductase activity was determined in $0.2 \mathrm{M}$ Tris- $\mathrm{HCl}$ buffer pH 6.8 in a final volume of $2.5 \mathrm{ml}$. containing I mM GSSG, 120 $\mu \mathrm{M}$ NADPH and enzyme, unless stated otherwise. A unit of activity is defined as the amount of enzyme required to oxidize I $\mu$ mole of NADPH per minute under the above conditions. The specific activity is defined as units/mg. protein. The protein content was determined by the method of Lowry, Rosebrough, Farr \& Randall (1951) with crystalline human serum albumin as standard.

\section{Purification of the Enzyme}

The purification procedure was carried out according to Staal et al. (1969), except that the last three steps were omitted and that the amount of DEAE-Sephadex suspension (step 2 and step 4) was doubled.

\section{Preparation of the Apoenzyme}

The apoenzyme was prepared according to Warburg \& Christian (1938). The enzyme solution was $55 \%$ saturated with $\left(\mathrm{NH}_{4}\right)_{2} \mathrm{SO}_{4}$ and was brought to $\mathrm{pH} 3^{\cdot}$ I with $\mathrm{I} \mathrm{N} \mathrm{HCl}$. After standing for 10 minutes in an ice bath, the apoenzyme was collected by centrifugation and was dissolved in $0.2 \mathrm{M}$ Tris buffer, $\mathrm{pH} 6.8$. This solution had only $8 \%$ of its original activity (rest-activity). In all recombination experiments of apoenzyme with FAD, the measured activities were corrected for the rest-activity.

\section{RESULTS}

\section{Purtfication of the enzyme}

Starting from $300 \mathrm{ml}$. of erythrocytes with a specific activity in the haemolysate of $5.2 \times \mathrm{IO}^{-3}$ units/mg. protein, an enzyme solution was obtained with a specific activity of 44 units $/ \mathrm{mg}$. protein. This means that the enzyme preparation was purified 8500 times.

\section{INFLUENCE OF COPPER ON THE HOLOENZYME}

FIG. I shows the influence of copper on the holoenzyme at three different GSSG concentrations. The inhibition of the enzyme by copper ions apparently depends on the GSSG

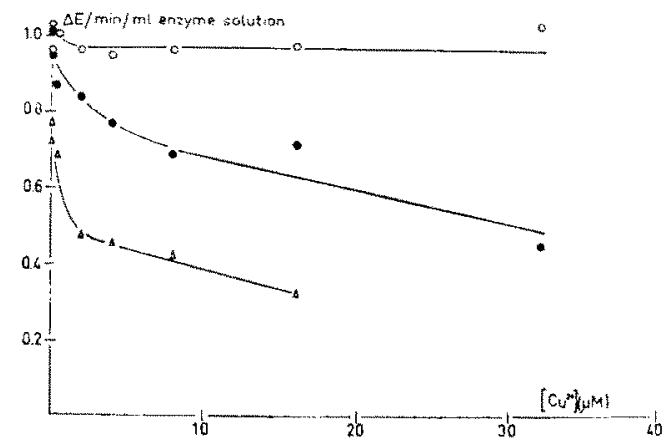

FIG. 1,-The influcnce of increasing $\mathrm{Cu}^{2+}$ concentration on glutathione reductase at different GSSG concentrations. $O$, I $\mathrm{mM}$ GSSG; $0.2 \mathrm{mM}$ GSSG; $\triangle$, $0.1 \mathrm{mM}$ GSSG. The reaction was started by adding enzyme solution to the cuvette. For further conditions see Methods.

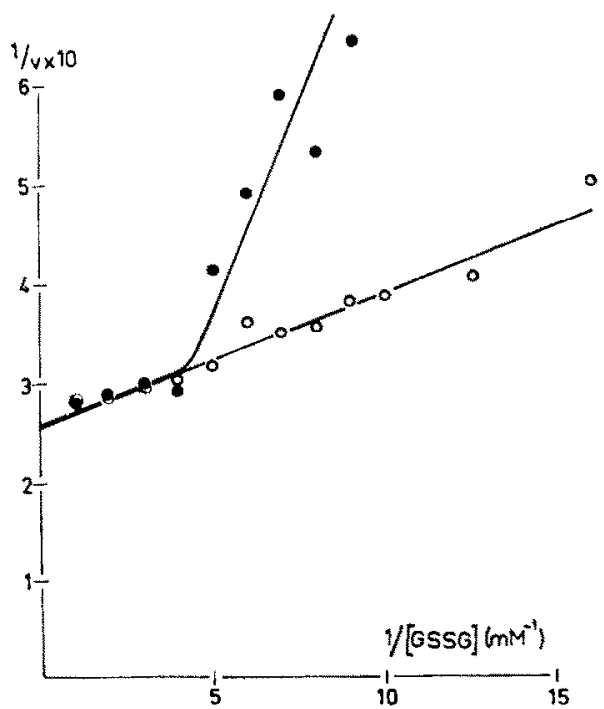

Frg. 2.-I/v against $1 /[$ GSSG] plot with (O) and without (O) copper. $\left[\mathrm{Cu}^{2+}\right]=2 \times 10^{-8} \mathrm{M}$. The reaction was started by adding enzyme solution to the cuvette. $v$ is expressed as $\Delta \mathrm{E} /$ minute/ml. enzyme solution. For further conditions see Methods. 
concentration. Increasing the copper concentrations up to $3.2 \times 10^{-5} \mathrm{M}$ no inhibition could be observed at all at a GSSG concentration of I $\mathrm{mM}$. However, at lower GSSG concentrations an inhibition by copper was found.

FIG. 2 is obtained by plotting $\mathrm{I} / v$ against I/[GSSG]; again it can be observed that the inhibition by copper started at a certain GSSG concentration. But it is quite difficult to conclude which mechanism of inhibition is involved.

Fig. 3 shows the $1 / v$ against $1 /[\mathrm{NADPH}]$

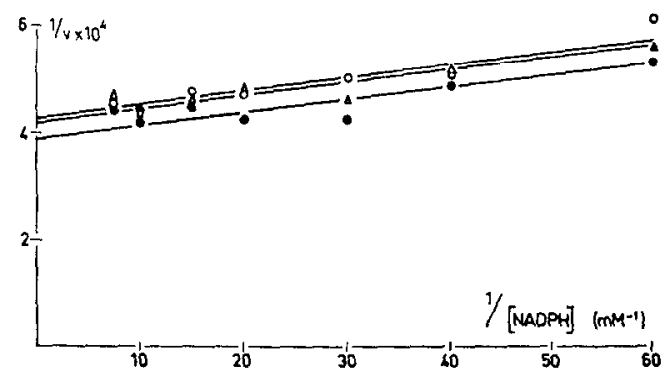

Fig. 3. $-1 / v$ against $1 /[\mathrm{NADPH}]$ plot at two different $\mathrm{Cu}^{2+}$ concentrations. $\mathrm{O}$, without copper; O ${ }^{1} 0^{-6} \mathrm{M} \mathrm{Cu}^{2+} ; \triangle, 2.5 \times 10^{-6} \mathrm{M} \mathrm{Cu}{ }^{2+}$. The reaction was started by adding enzyme solution to the cuvette. $v$ is expressed as $\Delta \mathrm{E} / \mathrm{minute} / \mathrm{ml}$. enzyme solution. For further conditions see Methods.

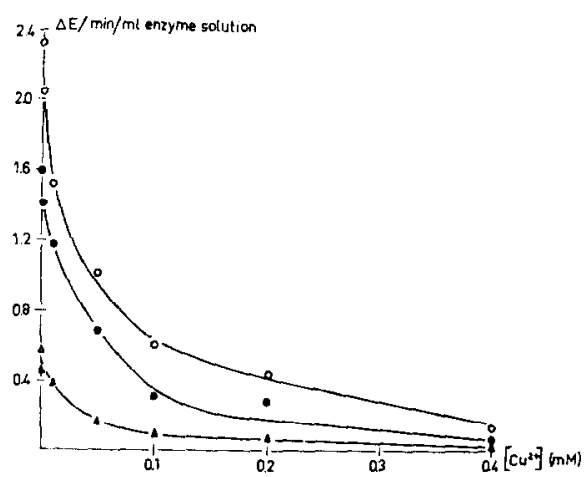

FIG. 4.-The influence of increasing $\mathrm{Cu}^{2+}$ concentration on the recombination of apoenzyme with FAD at three different concentrations. $O, 10^{-5} \mathrm{M}$ FAD;, $2 \times 10^{-6} \mathrm{M}$ FAD; $\triangle$, $5 \times 10^{-7} \mathrm{M}$ FAD. [GSSG] $=1 \mathrm{mM}$. The concentrations of $\mathrm{Cu}^{2+}$ and FAD in the preincubation mixture are as indicated. The reaction was started by adding $0.1 \mathrm{ml}$. preincubation mixture to the cuvette. For further conditions see Methods. plot with and without copper. From this plot it can be concluded that the copper inhibition is not influenced by the NADPH concentration. This is in contrast with reported observations (Fairbanks, I967).

\section{INFLUENCE OF COPPER ON THE}

\section{Regombination of Apoenzyme with FAD}

FIG. 4 shows the effect of copper on the recombination of the apoenzyme with three different FAD concentrations after Io minutes' preincubation. It is clear that the inhibition of the recombination depends on the FAD concentration. From the I/v against I/[FAD] plot with and without copper (FIG. 5) it can be concluded that copper is a competitive inhibitor towards FAD.

\section{Preingubation of Holoenzyme with COPPER}

In the recombination experiments we measured the enzyme activity after Io minutes preincubation of apoenzyme with FAD (with and without copper). Therefore, we also investigated the influence of copper on the holoenzyme by preincubating holoenzyme with copper. The results are given in Frg. 6. From these experiments it can be concluded that there is also an effect

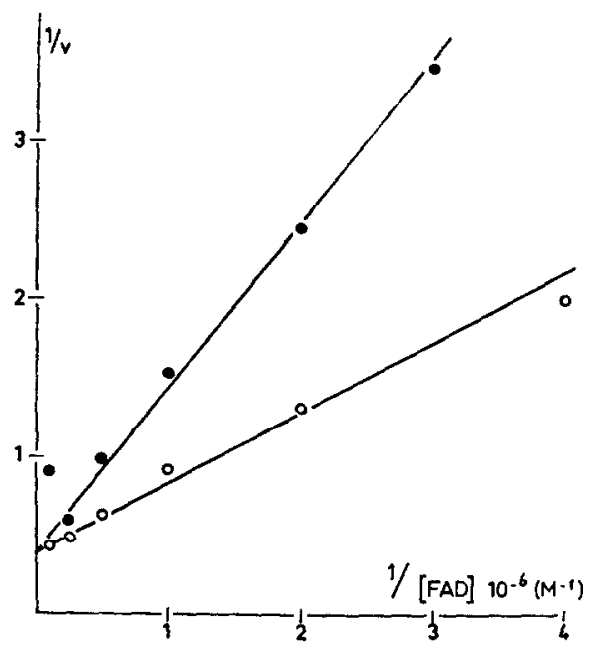

Frg. 5.- $1 / v$ against $\mathrm{I} /[\mathrm{FAD}]$ plot with (O) and without (O) $\mathrm{Cu}^{2+} .\left[\mathrm{Cu}^{2+}\right]=10^{-5} \mathrm{M}$; [GSSG] $=\mathrm{I} \mathrm{mM}$. $v$ is expressed as $\Delta \mathrm{E} /$ minute $/ \mathrm{ml}$. enzyme solution. For further conditions see FIG. 4. 


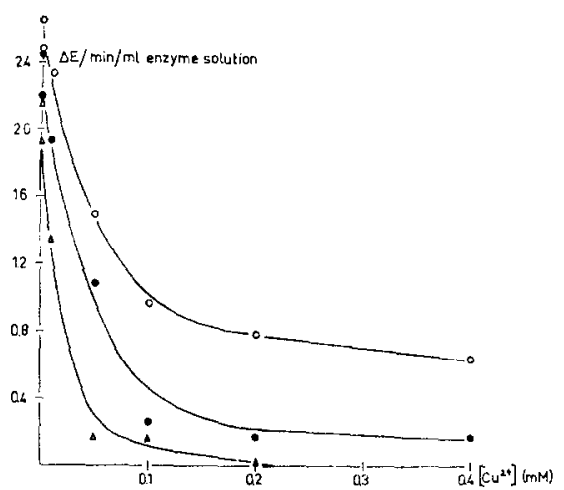

Fig. 6.-Influence of increasing $\mathrm{Cu}^{2+}$ concentration on holoenzyme preincubated with the indicated $\mathrm{Cu}^{2+}$ concentration at three different concentrations of GSSG. O, I.O mM GSSG; $0.2 \mathrm{mM}$ GSSG; $\triangle, 0.1 \mathrm{mM}$ GSSG. For further conditions see FIG. 4 .

of copper on the holoenzyme during preincubation. Howcver, when in the preincubation mixture besides holoenzyme and copper GSSG is added in a concentration of I $\mathrm{mM}$, it was found that the inhibition by copper was prevented (not shown). This means that the inhibitory effects of copper both on the recombination of apoenzyme with FAD and on the holoenzyme are dependent on the concentration of GSSG.

\section{DISCUSSION}

The results described in this paper clearly demonstrate that the influence of $\mathrm{Cu}^{2+}$ on glutathione reductase is strongly dependent on the GSSG concentration. This may explain the reason why Boulard et al. (1972) and Willms et al. (1972) did not find any inhibitory effect of copper on glutathione reductase, because their GSSG concentration was too high $(3.3 \mathrm{mM})$. Under these conditions the enzyme is saturated with GSSG substrate, because the $K_{m}$ for GSSG is about 0. I mM (Staal \& Veeger, I 969). The copper concentrations used in the experiments of Deiss et al. ( I 970) are so high that the effect of the GSSG concentration used in their experiments $(5.3 \mathrm{mM})$ is offset.

About the mode of action of copper on the holoenzyme one can only speculate. Direct GSSG binding by copper is unlikely, because copper ions chelate with two peptide molecules at most (Tommel, I969). From our experiments it can be seen that the GSSG-copper ratio at which the cnzymc is inhibited is much higher than two. SH-groups of the enzyme are probably involved in the inhibition by $\mathrm{Cu}^{2+}$. Studies on this subject are in progress.

Our recombination experiments indicate that copper is a competitive inhibitor of FAD-apoenzyme recombination at high physiological erythrocyte copper concentrations. This observation might be of value in the treatment of haemolytic anaemia caused by high erythrocyte copper concentrations. It is well-known that administration of riboflavin gives a higher content of FAD in the erythrocyte (Beutler, I969). In glutathione reductase deficiency, administration of riboflavin results in an increase of the glutathione reductase activity. Therefore, it seems reasonable to administer riboflavin to patients with chronic haematological disorders in which case it is often found that the copper content has increased.

\section{REFERENCES}

Beutler, E., (1969), ' Effect of flavin compounds on glutathione reductase activity: in vitro and in vivo studies', $\mathcal{F}$. Clin. Invest., 48, 1957I 966 .

Boulard, M., Blume, K. G., \& Beutler, E., ( 1972$)$ " The effect of copper on red cell enzyme activities ', 7. Clin. Invest., 5I, 459-46I.

Deiss, A., Lee, G. R., \& Cartwright, G. E., (1970), 'Hcmolytic ancmia in Wilson's disease', Ann. Intern. Med., 73, 413-418.

Fairbanks, V. F., (1967), 'Copper sulfateinduced hemolytic anemia', Archs. Intern. Med., 120, 428-432.

ICÉN, A., (1967), ' Glutathione reductase of human erythrocytes. Purification and properties', Scand. 7. Glin. Lab. Invest., 2o, suppl. gf.

Lowry, O. H., Rosebrough, N. J., FARR, A. L., \& Randall, R. J., (195I), ' Protein measurement with the Folin phenol reagent,, $\mathcal{F}$. Biol. Chem., 193, 265-275.

Manzler, A. D., \& Schreiner, A. W., (1970), 'Copper-induced acute hemolytic anemia', Ann. Intern. Med., 73, 409-412.

Metz, E. N., \& SAgOne, A. L., (I972), "The effect of copper on the erythrocyte hexose monophosphate shunt pathway', F. Lab. Clin. Med., 80, 405-413. 
Staal, G. E. J., Visser, J., \& Veeger, C., Warburg, O., \& Christian, W., (1938), (1969), 'Purification and properties of 'Bemerkung über gelbe Fermente', Biochem. glutathione reductase of human erythrocytes', Z., 298, 368-377. Biochim. Biophys. Acta, 185, 39-48.

StaAl, G. E. J., \& Veeger, C., (Ig69), "The reaction mechanism of glutathione reductase from human erythrocytes', Biochim. Biophys. Acta, 185, 49-62.

TommeL, D. K. J., (I969), ' Een methode voor de scheiding van peptiden van a-aminozuren', Thesis, Utrecht.

Willms, B., Blume, K. G., \& Löhr, G. W., (1972), 'Hernolytische Anämie bei Morbus Wilson (Hepatolentikuläre Degeneration)', Klin. Wschr., 50, 995-1002.

Key Word Index: Copper, glutathione reductase, apoenzyme, FAD. 